\title{
Estimasi jarak genetik, daya gabung gen dan heterosis bobot tubuh persilangan empat populasi ikan gurami, Osphronemus goramy, Lacepede 1801
}

\author{
[Estimates of genetic distance, combining ability and heterosis for body weight of cross four \\ populations of giant gourami, Osphronemus goramy Lacepede 1801]
}

\author{
Sularto $^{\bowtie}$, Rita Febrianti, Suharyanto \\ Balai Penelitian Pemuliaan Ikan \\ Jl. Raya 2 Sukamandi Pantura, Subang 41263
}

Diterima: 31 Desember 2016; Disetujui: 28 Maret 2017

\begin{abstract}
Abstrak
Hibridisasi merupakan salah satu cara untuk mendapatkan ikan gurami unggul. Penelitian ini bertujuan untuk mengestimasi jarak genetik empat populasi ikan gurami, yakni : Kalimantan, Jambi, Majalengka, dan Tasikmalaya, serta menghitung daya gabung gen serta heterosis persilangannya pada umur 11 bulan. Penelitian dilakukan di Balai Penelitian Pemuliaan Ikan Sukamandi. Perhitungan jarak genetik dilakukan berdasarkan karakterisasi truss morfometrik dengan jumlah sampel masing-masing hasil persilangan sebanyak 30 ekor dengan kisaran panjang baku 3,5-12,2 cm. Data dianalisis dengan analisis diskriminan dan dilanjutkan dengan "cluster procedure" untuk mendapatkan dendrogram menggunakan program SAS 6.03. Heterosis dihitung berdasarkan performa hibrida dibandingkan performa rata-rata induk tetuanya masing-masing pasangan induk terdiri atas 1 jantan dan 2 betina. Hasil penelitian ini menunjukkan bahwa keempat populasi ikan gurami mempunyai jarak genetik yang berbeda. Populasi gurami asal Kalimantan mempunyai jarak genetik terjauh dibandingkan dengan ketiga populasi lainnya, sedangkan ikan gurami asal Jambi dan asal Majalengka memiliki jarak genetik yang dekat. Populasi Jambi menunjukkan daya gabung umum tertinggi dengan nilai positif $21,82 \mathrm{~g}$. Nilai daya gabung spesifik tertinggi didapatkan dari persilangan antara betina Majalengka dengan jantan Jambi dengan nilai positif 75,30 g. Persilangan tersebut juga memiliki nilai heterosis tertinggi yaitu sebesar $41,78 \%$, selanjutnya diikuti persilangan betina Tasikmalaya dengan jantan Jambi sebesar 30,1\% dan persilangan betina Kalimantan dengan jantan Jambi sebesar 22,35\%. Ketiga persilangan tersebut prospektif untuk dijadikan ikan gurami hibrida unggulan.
\end{abstract}

Kata penting: daya gabung gen, heterosis, ikan gurami, jarak genetik

\begin{abstract}
The superior giant gourami can be obtained through hybridization. The purpose of this study was to estimate the genetic distance, combined ability, and crossbreeding heterosis at the age of eleven months from the four gourami populations: Kalimantan, Jambi, Majalengka, and Tasikmalaya. The study was conducted at the Research Institute for Fish Breeding Sukamandi. Genetic distance calculations were done by truss morphometric characterization with a sample of each of crossbred many as 30 individuals with the standard length range $3.5-12.2 \mathrm{~cm}$. The data was analyzed using discriminant analysis and continued with "cluster procedure" to get a dendrogram using SAS program 6:03. Heterosis was calculated based on the performance of the hybrid compared to the average performance parent each pair consisting of one male and two females. The results of this study showed that the four populations of giant gourami have different genetic distances. Giant gourami population from Borneo have the farthest genetic distance compared with the three other populations, whereas giant gourami from Jambi and from Majalengka has a close genetic distance. Jambi population shows the highest general combining ability with a positive value $21.82 \mathrm{~g}$. The highest value of specific combining ability is obtained from a cross between the Majalengka female with the Jambi male with a positive value $75.30 \mathrm{~g}$. The crosses also has the highest heterosis value that was equal to $41.78 \%$, follows by a cross between the Tasikmalaya female with the Jambi males (30.1\%) and a cross between the Borneo females with the Jambi males (22.35\%). The three crosses prospectively to produce superior hybrid of giant gourami.
\end{abstract}

Keywords: gene combining ability, heterosis, giant gourami, genetic distance

\section{Pendahuluan}

Salah satu cara untuk mendapatkan benih unggul dengan karakter tertentu selain melalui program seleksi dan rekayasa genetik, adalah

$\square$ Penulis korespondensi

Alamat surel: sularto61@yahoo.com melalui program hibridisasi. Capaian hasil melalui program hibridisasi membutuhkan waktu yang lebih singkat dibandingkan melalui program seleksi, asalkan telah didapatkan persilangan atau hibrida yang memiliki nilai heterosis 
yang tinggi sesuai dengan target peningkatan nilai genetik (genetic gain) yang diinginkan. Program hibridisasi cocok diterapkan terutama pada ikan yang memiliki waktu awal matang gonad relatif lama seperti ikan gurami yaitu dua tahun (Febrianti et al. 2016). Gjedrem (2005) mendefinisikan bahwa hibridisasi adalah persilangan antarspesies, keturunan, populasi, strain atau galur murni yang berbeda untuk mendapatkan keturunan yang lebih baik (hybrid vigor). Hibridisasi dapat diikutkan dalam program seleksi sebagai tahap persilangan akhir untuk menimbulkan peningkatan ekspresi pertumbuhan ikan.

Apabila nilai koefisien variasi kecil atau varian genetik aditif yang dapat dieksploitasi kecil, maka tidak memungkinkan untuk memperbaiki suatu fenotipe kuantitatif melalui program seleksi. Salah satu teknik yang dapat digunakan untuk memperbaiki performa tersebut adalah melalui program hibridisasi (crossbreeding). Menurut Gjedrem (2005), hibridisasi dapat meningkatkan heterozigositas dan menurunkan proporsi homozigositas gen serta jika bahan dasarnya memiliki kekerabatan yang jauh, maka akan menghasilkan keturunan yang memiliki performa yang lebih baik dibanding tetuanya. Hibridisasi memperbaiki produktivitas dengan cara mengeksploitasi varian genetik dominan. Prinsip dasar hibridisasi adalah memunculkan kembali kombinasi baru pasangan alel-alel yang berinteraksi. Bilamana dalam pasangan alel-alel yang berinteraksi terdapat alel dominan yang bersifat superior, maka akan memperbaiki performa keturunannya.

Hibridisasi akan berhasil apabila diawali dengan informasi yang jelas tentang induk pembentuknya. Informasi penting yang harus diketahui antara lain: jarak genetik, daya gabung gen, dan nilai heterosis. Jarak genetik perlu diketahui untuk memprediksi kemungkinan apa yang diperoleh dari kegiatan hibridisasi tersebut. Apabila ke- dua induk memiliki jarak genetik yang jauh, maka dimungkinkan akan memunculkan hybrid vigor pada hibridanya (Rahman et al. 1995, Ding et al. 2007). Bila jarak genetiknya dekat, maka yang diharapkan adalah kecocokan gen atau daya gabung dari kedua induk pembentuknya sehingga menghasilkan ikan hibrida yang memiliki nilai heterosis positif (Falconer 1981). Dalam suatu pengembangan program seleksi yang efektif adalah penting untuk memiliki informasi dasar genetik untuk ciri-ciri penting seperti pertumbuhan dan resistensi terhadap penyakit (Wang et al. 2006)

Hibridisasi telah digunakan pada banyak spesies untuk meningkatkan laju pertumbuhan, memanipulasi nisbah jenis kelamin, menghasilkan hewan steril, meningkatkan kualitas daging, meningkatkan ketahanan terhadap penyakit, meningkatkan lingkungan toleransi, dan meningkatkan berbagai sifat yang diinginkan lainnya untuk membuat budi daya lebih menguntungkan (Bartley et al. 2001). Bukti performa yang unggul dan hybrid vigor telah dilaporkan dalam berbagai macam jenis ikan (Wohlfarth 1993, Bartley et al. 2001).

Superioritas hibrida dapat diukur sebagai nilai heterosis atau hybrid vigour yang dapat mengevaluasi persentase peningkatan performa relatif hibrid tersebut (Gjedrem 2005). Efek heterosis ditampakkan pada persilangan antara ikan Ictalurus punctatus (bobot rata-rata $460 \mathrm{~g}$ ) dan Ictalurus furcatus (bobot rata-rata $440 \mathrm{~g}$ ) yang memberikan nilai heterosis sebesar $18 \%$ pada bobot rata-rata hibrid (Tave 1995). Contoh lain adalah persilangan antara Oreochromis aureus $\mathrm{x}$ Oreochromis spirulus dan Oreochromis mossambicus $x$ Oreochromis niloticus menghasilkan nilai heterosis 22\% dan 25\% (Tayamen et al. 2002). Persilangan antara ikan gurami Strain Bastar dan 
Bluesaphire menghasilkan nilai heterosis 2,37\% pada sintasan larva (Radona \& Nafiqoh 2014).

Ikan gurami yang dibudidayakan oleh masyarakat tidak banyak diketahui karakter genetiknya. Sampai saat ini baru ada satu strain ikan gurami hasil pemuliaan yaitu ikan gurami TO ("tutug oncom") yang dihasilkan oleh Balai Pengembangan Budidaya Ikan Gurami dan Nilem (BPBIGN) Singaparna, namun belum banyak tersebar di kalangan masyarakat pembudidaya.

Penelitian ini bertujuan untuk mengestimasi jarak genetik, daya gabung, dan nilai heterosis persilangan empat populasi ikan gurami (Kalimantan, Jambi, Majalengka, dan Tasikmalaya).

\section{Bahan dan metode}

Penelitian dilaksanakan di Balai Penelitian Pemuliaan Ikan (BPPI) Sukamandi pada bulan Juni 2014 - bulan Mei 2015. Ikan uji adalah anak ikan gurami berumur 11 bulan hasil persilangan empat populasi ikan gurami yang berasal dari Kalimantan Selatan (K), Jambi (strain Batang hari) (J), Majalengka (M), dan Tasikmalaya (T) secara resiprokal, sehingga dipasangkan 16 persilangan.

Pemijahan induk ikan gurami dilakukan menggunakan dua buah kolam tanah berukuran $400 \mathrm{~m}^{2}$ yang disekat dengan waring menjadi 12 bagian yang sama, sehingga setiap sekat berukuran sekitar $33 \mathrm{~m}^{2}$. Tiap-tiap pasangan induk dengan nisbah jantan betina 1:2 ditempatkan pada masing-masing sekat secara terpisah yang penempatannya dilakukan secara acak.

Telur yang dihasilkan dipisahkan antara telur yang terbuahi (fertilized egg) dengan tidak terbuahi (unfertilized egg). Telur yang terbuahi dicirikan dengan kondisi transparan, sedangkan telur yang tidak terbuahi bewarna kuning. Telur yang terbuahi dipelihara dengan cara diinkubasikan di dalam baskom berukuran volume air $30 \mathrm{~L}$ dengan kepadatan 100 butir $\mathrm{L}^{-1}$ selama 7 hari sampai menetas menjadi larva.

Pendederan larva (pendederan pertama) dilakukan di dalam akuarium dengan kepadatan 75 ekor $\mathrm{L}^{-1}$. Pakan yang diberikan berupa cacing sutera (Tubifex sp.) secara ad libitum selama dua minggu.

Pendederan kedua dilakukan di kolam tembok berukuran $25 \mathrm{~m}^{2}$ dengan kedalaman air $40 \mathrm{~cm}$ dan padat tebar 100 ekor $\mathrm{m}^{-2}$ selama 2,5 bulan. Pakan yang diberikan berupa pellet dengan kandungan protein $38-40 \%$ sebanyak $20 \%$ bobot badan $\mathrm{hr}^{-1}$. Setelah satu bulan pemeliharaan, jumlah pemberian pakan diturunkan menjadi $10 \%$ bobot biomassa per hari dan setelah dua bulan pemeliharaan mulai diberi pakan daun sente (Alocasia macrorrhiza Schott.) sebanyak 2\%. Setelah didederkan di kolam tembok selama 2,5 bulan, anak ikan gurami mencapai ukuran 5-10 g. Pada ukuran tersebut sudah siap dibesarkan di kolam tanah.

Dalam penelitian ini yang berhasil dipelihara dengan jumlah yang cukup hanya ada 12 famili. Pembesaran di kolam tanah dengan kedalaman air 80-100 cm menggunakan kolam $400 \mathrm{~m}^{2}$ yang disekat menjadi 12 bagian yang sama atau sekitar $33 \mathrm{~m}^{2}$, ditebar anak ikan berukuran 5-10 g dengan kepadatan 30 ekor $\mathrm{m}^{-2}$. Pakan yang diberikan berupa pellet dengan kadar protein 28-30\% sebanyak $5 \%$ bobot biomassa $\mathrm{hr}^{-1}$ dan $2 \%$ daun sente (Alocasia macrorrhiza Schott.). Setelah enam bulan pemeliharaan di kolam tanah, pemberian pakan diturunkan menjadi 3\% bobot biomassa $\mathrm{hr}^{-1}$, sedangkan pemberian daun sente te$\operatorname{tap} 2 \%$.

Ikan uji yang digunakan dalam penelitian ini berumur 11 bulan. Pada pengukuran hetererosis digunakan 12 famili, yaitu empat famili induk tetua dan delapan persilangannya yaitu: $q$ Majalengka x $\lesssim$ Jambi (MJ), $q$ Kalimantan x $\precsim$ Jambi $(\mathrm{KJ})$, + Kalimantan X $\widehat{\jmath}$ Majalengka (KM), ㅇ 
Tasikmalaya X $\precsim$ Jambi (TJ), $q$ Kalimantan X $ぇ$ Tasikmalaya (KT), + Jambi X $\curvearrowright$ Kalimantan (JM), $q$ Jambi X $ð$ Majalengka (JM), dan $q$ Majalengka X $\curvearrowright$ Kalimantan (MK). Jumlah individu masing-masing famili sebanyak 193300 ekor.

Ikan uji yang digunakan dalam uji morfometrik berukuran panjang baku berkisar antara 3,512,2 cm, masing-masing sebanyak 30 ekor berasal dari famili populasi asal Kalimantan, Jambi, Majalengka, dan Tasikmalaya. Karakter morfometrik yang diukur meliputi: ujung mulut - dahi (A1), dahi - pangkal sirip punggung (A2), pangkal sirip punggung - pangkal sirip perut (A3), ujung mulut - pangkal sirip perut (A4), dahi pangkal sirip perut (A5), ujung mulut - pangkal sirip punggung (A6), pangkal sirip punggung ujung sirip punggung (B1), ujung sirip punggung - ujung sirip anal (B2), pangkal sirip perut ujung sirip anal (B3), pangkal sirip punggung ujung sirip anal (B4), pangkal siirip perut - ujung sirip punggung (B5), ujung sirip punggung pangkal atas sirip ekor (C1), pangkal atas sirip ekor - pangkal bawah sirip ekor (C2), ujung sirip anal - pangkal bawah siirip ekor (C3), ujung sirip punggung - pangkal bawah sirip ekor (C4), ujung sirip anal - pangkal atas sirip ekor (C5); dan panjang baku (PB) yang digunakan sebagai pembagi nisbah ukuran (Kusmini et al. 2000, Setijaningsih et al. 2007).

\section{Analisis data}

Data morfometrik dianalisis menggunakan prosedur diskriminan (Discriminant Procedure) dengan bantuan program statistik SAS versi 6.03 (SAS 1988). Dari hasil perhitungan tersebut dihasilkan jarak genetik kuadrat (squared genetic distance) kemudian dilanjutkan dengan analisis klaster (cluster procedure) dengan menggunakan program SAS versi 6.03 (SAS 1988) untuk mendapatkan dendrogram (Nei 1972)

Nilai heterosis populasi hasil persilangan dihitung dengan menggunakan rumus (Tave 1993):

$$
H=\frac{(\mathrm{F} 1-1 / 2(\mathrm{P} 1+\mathrm{P} 2)}{1 / 2(\mathrm{P} 1+\mathrm{P} 2)}
$$

Keterangan: $\mathrm{H}=$ heterosis $(\%), \mathrm{F} 1=$ performa persilangan, $(\mathrm{P} 1+\mathrm{P} 2)=$ performa tetua

Daya gabung gen (genetic combining ability) yang dihitung dalam penelitian ini terdiri atas daya gabung umum (general combining ability) dan daya gabung spesifik (specific combining ability). Daya gabung gen tersebut dihitung menggunakan rumus (Gjedrem 2005):

$$
\mathrm{GCA}=1 / \mathrm{n}(\mathrm{Si} .+\mathrm{S} . \mathrm{i})-\mathrm{S} / \mathrm{n}
$$

$\mathrm{SCA}(\mathrm{A} \times \mathrm{B})=(\mathrm{A} \times \mathrm{B})-\mathrm{GCA}(\mathrm{A})-\mathrm{GCA}(\mathrm{B})-\mathrm{S} / 8$

Keterangan: $\mathrm{GCA}=$ daya gabung umum, $\mathrm{S} . \mathrm{i}=$ kumulatif performa persilangan jantan ke-I, Si.= kumulatif performa persilangan betina ke-I, $\mathrm{S}=$ total performa semua persilangan, $\mathrm{S} / \mathrm{n}=$ rataan performa semua persilangan, $n=$ jumlah persilangan, $\mathrm{SCA}=$ daya gabung spesifik, $\mathrm{A}$ dan $\mathrm{B}=$ kode persilangan

\section{Hasil}

Indeks kesamaan

Analisis diskriminan menghasilkan indeks kesamaan antarpopulasi seperti tertera pada Tabel 1. Populasi Kalimantan tidak memiliki nilai kesamaan dengan populasi Majalengka dan Tasikmalaya, namun memiliki sedikit kesamaan dengan populasi Jambi yaitu sebesar 13,33\%. Populasi Jambi memiliki kesamaan dengan populasi Majalengka sebesar $36,67 \%$, dengan populasi Kalimantan 6,67\% dan dengan populasi Tasikmalaya 3,33\%. Populasi Majalengka memiliki kesamaan dengan populasi Jambi dan populasi Tasikmalaya sebesar 13,33\%. Populasi Tasikmalaya berbeda dengan populasi lainnya dan hanya memiliki kesamaan 3,33\% dengan populasi Majalengka. 
Tabel 1 Persentase indeks kesamaan antarpopulasi ikan gurami (Osphronemus goramy)

\begin{tabular}{lccccc}
\hline \multirow{2}{*}{ Dari populasi } & \multicolumn{5}{c}{ Ke populasi } \\
\cline { 2 - 6 } Kalimantan & Kalimantan & Jambi & Majalengka & Tasikmalaya & Total \\
& 26 & 4 & 0 & 0 & 30 \\
Jambi & 86,67 & 13,33 & 0,00 & 0,00 & 100,00 \\
& 2 & 16 & 11 & 1 & 30 \\
Majalengka & 6,67 & 53,33 & 36,67 & 3,33 & 100,00 \\
& 0 & 4 & 22 & 4 & 30 \\
Tasikmalaya & 0,00 & 13,33 & 73,33 & 13,33 & 100,00 \\
& 0 & 0 & 1 & 29 & 30 \\
Total & 0,00 & 0,00 & 3,33 & 96,67 & 100,00 \\
& 28 & 24 & 34 & 34 & 120 \\
& 23,33 & 20,00 & 28,33 & 28,33 & 100,00 \\
\hline
\end{tabular}

Jarak genetik

Berdasarkan jarak genetik empat populasi ikan gurami, seperti terlihat pada Gambar 1, ternyata populasi asal Kalimantan memiliki jarak genetik terjauh dibandingkan populasi lainnya. Populasi yang memiliki jarak genetik terendah adalah populasi Jambi dan populasi Majalengka.

\section{Daya gabung gen}

Hasil perhitungan daya gabung gen ditampilkan pada Tabel 2. Nilai daya gabung umum (DGU) tertinggi didapatkan pada hasil perkawinan dengan populasi Jambi, dengan nilai DGU positif 21,82 g diikuti dengan galur murni Tasik, Majalengka, dan terendah Kalimantan dengan nilai negatif $19,20 \mathrm{~g}$. Nilai daya gabung spesifik tertinggi didapatkan dari persilangan antara betina Majalengka dengan jantan Jambi dengan nilai positif 75,30 g, sedangkan yang terendah adalah persilangan antara betina Majalengka dengan jantan Kalimantan dengan nilai negatif 52,99 g.

\section{Heterosis}

Nilai heterosis masing-masing persilangan dapat dilihat pada Tabel 3. Berdasarkan hasil perhitungan nilai heterosis tidak semua persilangan memperlihatkan nilai heterosis positif. Dari delapan persilangan ada enam persilangan menunjukkan heterosis positif yaitu nilai tertinggi didapatkan hasil persilangan antara betina Majalengka dengan jantan Jambi sebesar 41,78\%

Dendrogram using Average Linkage (Between Groups)

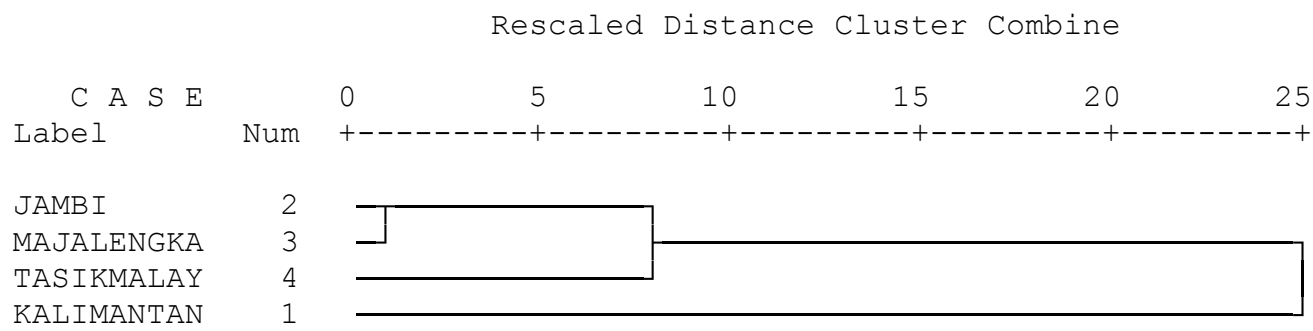

Gambar 1 Dendrogram jarak genetik empat populasi ikan gurami (Osphronemus goramy) 
Tabel 2 Daya gabung umum ( $D G U$ ) dan daya gabung spesifik (DGS) empat persilangan populasi gurami

\begin{tabular}{|c|c|c|c|}
\hline Peringkat & Genotipe & Nilai DGU (g) & Nilai DGS (g) \\
\hline 1 & Jambi & 21,82 & \\
\hline 2 & Tasik & 11,76 & \\
\hline 3 & Majalengka & $-9,20$ & \\
\hline 4 & Kalimantan & $-19,17$ & \\
\hline 1 & $q$ Majalengka x $\precsim$ Jambi & & 75,30 \\
\hline 2 & $q$ Kalimantan $\mathrm{x} \precsim \widehat{J} \mathrm{Jambi}$ & & 25,99 \\
\hline 3 & q Kalimantan X $\widehat{\jmath}$ Majalengka & & 9,98 \\
\hline 4 & o+ Tasikmalaya X $\precsim$ Jambi & & $-0,69$ \\
\hline 5 & q Kalimantan X $\hat{o}$ Tasikmalaya & & $-1,96$ \\
\hline 6 & + Jambi X $\widehat{\partial}$ Kalimantan & & $-18,03$ \\
\hline 7 & q Jambi X $\widehat{\partial}$ Majalengka & & $-37,59$ \\
\hline 8 & ○ Majalengka X $\widehat{\partial}$ Kalimantan & & $-52,99$ \\
\hline
\end{tabular}

Tabel 3 Bobot rataan, simpangan baku, koefisien keragaman, dan nilai heterosis

\begin{tabular}{cccccc}
\hline Famili & $\begin{array}{c}\text { Rataan populasi } \\
(\mathrm{g})\end{array}$ & $\begin{array}{c}\text { Simpangan baku } \\
(\mathrm{g})\end{array}$ & Koefisien keragaman & \multicolumn{2}{c}{ Nilai heterosis } \\
$(\mathrm{g})$ & $(\%)$ \\
\hline KK & 341,66 & 49,60 & 0,15 & & \\
JJ & 280,18 & 37,43 & 0,13 & & \\
MM & 340,06 & 54,59 & 0,16 & & \\
TT & 311,15 & 42,07 & 0,14 & & \\
MJ & 439,68 & 122,77 & 0,28 & 129,56 & 41,78 \\
TJ & 384,65 & 85,88 & 0,22 & 88,98 & 30,10 \\
KJ & 380,40 & 85,98 & 0,23 & 69,48 & 22,35 \\
KT & 342,39 & 111,55 & 0,33 & 15,99 & 4,90 \\
JK & 336,39 & 85,31 & 0,25 & 25,47 & 8,19 \\
KM & 333,38 & 101,96 & 0,31 & $-7,49$ & $-2,20$ \\
JM & 326,79 & 76,83 & 0,24 & 16,67 & 5,37 \\
MK & 270,41 & 65,66 & 0,24 & $-70,46$ & $-20,67$ \\
\hline
\end{tabular}

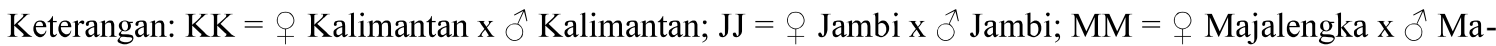

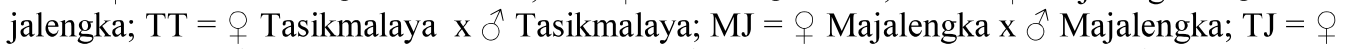

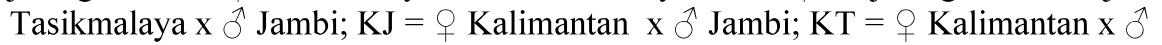

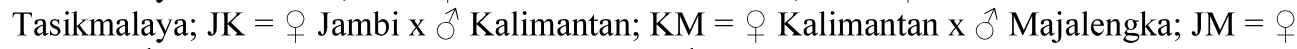

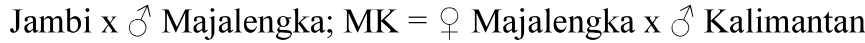

dan dua persilangan yang menunjukkan heterosis negatif yaitu persilangan antara betina Kalimantan dengan Jantan Majalengka (- 2,20 g) dan persilangan antara betina Majalengka dengan jantan Kalimantan sebesar -20,67 g. Populasi Kalimantan dan Majalengka mempunyai variabilitas lebih tinggi dibandingkan dengan populasi Jambi dan Tasikmalaya.

Secara keseluruhan persilangan dengan jantan Jambi memiliki nilai heterosis yang relatif tinggi yakni di atas $20 \%$. Persilangan antara betina Majalengka dengan jantan Jambi memiliki 
nilai heterosis tertinggi yaitu $41,78 \%$ pada karakter bobot, meskipun kedua induk memiliki jarak genetik yang dekat (Gambar 1).

\section{Pembahasan}

\section{Indeks kesamaan}

Berdasarkan nilai kesamaan populasi Tasikmalaya memiliki tingkat kesamaan tertinggi dalam populasinya yaitu sebesar 96,67\%. Hal tersebut diduga karena populasi tersebut merupakan populasi yang sedang dilakukan proses pembentukan strain yang dijaga kemurniannya dan telah dilakukan proses seleksi yang ditunjukkan dengan nilai koefisien keragaman yang relatif lebih rendah. Populasi Kalimantan memiliki nilai kesamaan yang relatif tinggi dalam populasinya yaitu sebesar $86,67 \%$, hal tersebut dapat dipahami pula karena populasi Kalimantan merupakan populasi alam (wild populations) yang ditunjukkan dengan nilai koefisien keragaman yang relatif lebih tinggi. Populasi tersebut belum banyak dibudidayakan oleh masyarakat, sehingga belum terjadi persilangan dengan populasi lainnya. Seperti dilaporkan oleh Samaradivakara et al. (2012), tingkat kesamaan berbanding terbalik dengan variabilitas.

\section{Jarak genetik}

Berdasarkan jarak genetik empat populasi ikan gurami yang digunakan sebagai tetua ternyata populasi asal Kalimantan memiliki jarak genetik terjauh dibandingkan populasi lainnya. Jarak genetik merupakan tingkat perbedaan gen di antara populasi atau spesies (Nei 1987). Pada umumnya ikan yang memiliki jarak genetik yang jauh akan menghasilkan nilai heterosis yang tinggi, namun demikian dalam penelitian ini persilangan populasi Kalimantan dengan populasi lainnya tidak memberikan nilai heterosis positif. Hal ini diduga tidak didukung dengan daya ga- bung gen atau kecocokan gen yang baik secara individu. Dalam kasus ini perlu dicari individu yang memiliki daya gabung gen atau kecocokan gen dengan populasi lainnya dengan cara memijahkan lebih banyak pasangan induk secara terkontrol. Populasi Kalimantan berasal dari populasi alam (wild populations), belum banyak dibudidayakan masyarakat, sedangkan populasi Jambi, Majalengka, dan Tasikmalaya merupakan hasil budi daya. Populasi Jambi memiliki jarak genetik yang dekat dengan populasi Majalengka, hal ini diduga memiliki nenek moyang yang sama. Seperti dilaporkan oleh Nugroho \& Kusmini (2007), Nugroho (2011), dan Nugroho et al. (2013) bahwa ikan gurami ras Soang/ Bastar, Paris, Blusafir, dan Batanghari memiliki kesamaan secara genetik.

\section{Daya gabung gen}

Berdasarkan nilai daya gabung umum (general combining ability) populasi asal Jambi memiliki daya gabung tertinggi dan bernilai positif dan diikuti populasi Tasik, Majalengka, dan terendah populasi Kalimantan. Menurut Falconer (1981), daya gabung umum mencerminkan efek genetik-aditif, sedangkan nilai daya gabung spesifik mencerminkan dominansi, dominansi x genetik, dan dominansi $\times$ interaksi efek dominansi. Wang et al. (2006) melaporkan hasil penelitian pada hibrida ikan kakap (Morone chrysops $q \times$ Morone saxatilis $\widehat{\delta}$ ) bahwa efek gen aditif sebagian besar berkontribusi terhadap perbedaan genetik dalam pertumbuhan benihnya. Perbaikan genetik sifat pertumbuhan dimungkinkan dengan memanfaatkan gen aditif dan non-aditif untuk memperbaiki hybrid vigor (Su et al. 2013).

\section{Heterosis}

Berdasarkan nilai heterosisnya secara keseluruhan persilangan dengan jantan Jambi memi- 
liki nilai heterosis yang relatif tinggi yakni di atas 20\%. Persilangan antara betina Majalengka dengan jantan Jambi memiliki nilai heterosis tertinggi yaitu $41,78 \%$ pada karakter bobot, padahal kedua induk memiliki jarak genetik yang dekat. Menurut Falconer (1981) bila jarak genetiknya dekat, maka yang diharapkan adalah kecocokan gen atau daya gabung dari kedua induk pembentuknya sehingga menghasilkan ikan hibrida yang memiliki nilai heterosis positif. Data tersebut juga mengindikasikan bahwa jantan Jambi memiliki gen aditif serta memberikan efek dominan pada keturunannya dari ketiga pasangan betina tersebut, sehingga dapat dikatakan bahwa jantan Jambi sebagai penggabung yang baik (combainer). Seperti dilaporkan oleh $\mathrm{Su}$ et al. (2013), bahwa ikan mas Jian (Cyprinus carpio L,) adalah penggabung terbaik untuk bobot badan. Persilangan dengan jantan lainnya memiliki nilai heterosis kurang dari $10 \%$, bahkan persilangan KM dan MK memberikan nilai heterosis negatif. Seperti dilaporkan oleh Radona \& Nafikoh (2014) persilangan $q$ Bluesafir x $\curvearrowright$ Bastar menghasilkan nilai heterosis negatif $(-2,79 \%)$ pada karakter sintasan. Menurut Nugroho \& Kusmini (2007), rendahnya nilai heterosis bukan berarti keturunan hasil persilangan jelek tetapi lebih menerangkan atau menggambarkan suatu kondisi perbandingan antara rata-rata keturunan dengan rata-rata kedua tetuanya.

Berdasarkan Tabel 3 secara keseluruhan hibridisasi dapat meningkatkan heterosis dan variabilitas. Menurut Su et al. (2013) persilangan dialel (diallel crossing) biasanya dilakukan untuk meningkatkan performa pertumbuhan serta peningkatan hasil dan ketahanan terhadap penyakit. Berdasarkan data dari persilangan dialel, strain dengan GCA (general combining ability) dan SCA (specific combining ability) tertinggi dapat dipilih sebagai indukan terbaik. Analisis daya gabung digunakan untuk mengidentifikasi tetua dengan GCA tinggi dan mengacu pada performa rata-rata tetuanya pembentuk hibrida dan kombinasi indukan dengan SCA tinggi (Su et al. 2013). Selanjutnya ditegaskan pula bahwa indukan penggabung (combiner) terbaik dapat digunakan dalam program hibrisasi untuk mengeksploitasi heterosis.

Menurut Nugroho \& Kusmini (2014), tingkat variasi heterozigositas dipengaruhi oleh jenis ras ikan gurame. Secara umum ras ikan gurame yang diteliti mempunyai tingkat keragaman yang tinggi dengan nilai heterozigositas rata-rata 0,2747, dengan nilai tertinggi terdapat pada ras Bluesafir $(0,3050)$ kemudian diikuti oleh ras $\mathrm{Pa}-$ ris $(0,2832)$ dan Bastar $(0,2360)$. Menurut Ariyanto \& Utami (2006), tingginya nilai estimasi heterosis menunjukkan bahwa nilai kekerabatan spesies tersebut relatif jauh.

Dari hasil persilangan empat populasi ikan gurami tersebut ternyata ada dua persilangan yang memiliki nilai heterosis negatif, artinya pertumbuhan ikan gurami hibrida lebih lambat dibandingkan dengan rata-rata kedua tetuanya, yaitu pada perilangan antara populasi Kalimantan dan Majalengka secara resiprokal. Menurut Wohlfarth (1993), heterosis adalah pertumbuhan yang melebihi dari pertumbuhan tercepat strain parental, dan menunjukkan bahwa heterosis untuk pertumbuhan dalam spesies ini adalah umum, namun tidak semuanya seperti itu. Namun menurut Nugroho \& Kusmini (2007), nilai heterosis yang rendah (negatif) bukan berarti keturunan hasil persilangan jelek tetapi lebih menerangkan atau menggambarkan suatu kondisi perbandingan antara rata-rata keturunan dengan rata-rata kedua tetuanya.

Persilangan antara betina Majalengka dengan jantan Jambi memiliki nilai daya gabung spesifik tertinggi dengan nilai positif 75,30 g 
serta memiliki nilai heterosis tertinggi yaitu $41,78 \%$, hal ini merupakan kandidat sebagai ikan hibrida prospektif untuk ikan budi daya yang memiliki pertumbuhan cepat.

\section{Simpulan}

Dari hasil penelitian ini dapat disimpulkan bahwa populasi ikan gurami asal Kalimantan mempunyai jarak genetik terjauh dengan ketiga lainnya, sedangkan ikan gurami asal Jambi mempunyai jarak genetik yang dekat dengan ikan gurami asal Majalengka. Secara umum populasi gurami asal Jambi mempunyai kemampuan daya gabung lebih baik dibandingkan dengan ketiga populasi lainnya. Persilangan yang mempunyai kemampuan daya gabung spesifik tertinggi adalah betina Majalengka dan jantan Jambi yaitu sebesar 75,30 g dan memiliki nilai heterosis yang tertinggi yaitu sebesar $41,78 \%$.

\section{Persantunan}

Penelitian ini dibiayai dari dana APBN Balai Penelitian Pemuliaan Ikan tahun anggaran 2014 dan 2015. Ucapan terima kasih disampaikan kepada teman-teman teknisi Komoditas Gurami: Pak A. Sofyan Suri, Pak Sugio, dan Pak Nurdiyansyah, yang telah banyak membantu dalam pengumpulan data dengan penuh dedikasi.

\section{Daftar pustaka}

Ariyanto D, Utami R. 2006. Evaluasi laju pertumbuhan, keragaman pertumbuhan dan estimasi heterosis pada persilangan antar spesies ikan patin (Pangasius sp.). Jurnal Perikanan), 8(1): 81-86.

Bartley D, Rana MK, Immink AJ. 2001. The use of interspecific hybrids in aquaculture and fisheries. Reviews in Fish Biology and Fisheries, 10(3): 325-337.

Ding J, Chang Y, Wang C, Cao X. 2007. Evaluation of the growth and heterosis of hybrids among three commercially important sea urchins in China: Strongylocentrotus nudus,
S. intermedius and Anthocidaris crassispina. Aquaculture, 272(-4): 273-280.

Falconer DS. 1981. Introduction to Quantitative Genetics, 2nd edition. Longman Inc, United Kingdom. 464 p.

Febrianti R, Sularto, Suharyanto, 2016, Penentuan awal jenis kelamin pada ikan gurami (Osphronemus goramy Lacepede 1801). In: Zahid A, Simanjuntak CPH, Lusiastuti AM, Rahardjo MF, Hadiaty RK, Hadie W, Hadie LE (Editor). Prosiding Seminar Nasional Ikan ke-9. Masyarakat Iktiologi Indonesia, Cibinong. pp 505-512.

Gjedrem T. 2005. Selection and Breeding Programs in Aquaculture, Springer Link, Netherlands Publisher, $364 \mathrm{p}$.

Kusmini II, Hadie LE, Hadie W, Kristanto AH, 2000, Karakterisasi dalam karakter fenotip beberapa ras ikan gurame (Osphronemus gouramy) yang berpotensi dalam budidaya dengan analisis truss morfometrik. Prosiding Simposium Nasional Pengelolaan Plasma Nutfah, Bogor. pp. 614-620.

Nei M. 1972, Genetic distance between populations. The American Naturalist, 106(949): 283-292.

Nei M. 1987. Moleculer Evolutionary Genetics. Columbia University Press, New York. 512p

Nugroho E. 2011, Evaluasi variasi genetik rasras ikan gurame dengan menggunakan marker DNA. Jurnal Perikanan, 13(2): 86-90.

Nugroho E, Rahayuni E, Hamid MA. 2013. Gurami Batanghari: Benarkah strain berbeda? Suatu kajian genetik dengan menggunakan marka molekuler DNA, Media Akuakultur, 8(1): 9-12.

Nugroho E, Kusmini II. 2007. Evaluasi variasi genetik tiga ras ikan gurame (Osphronemus gourami) dengan menggunakan metode isozyme. Jurnal Riset Akuakultur, 2(1): 51-57.

Radona D, Nafiqoh N. 2014. Karakterisasi reproduksi dan nilai heterosis hasil persilangan ikan gurame bastar dan bluesafir. Berita Biologi, 13(2): 153-159.

Rahman MA, Bhadra A, Begum N, Islam MS, Hussain MG, 1995, Production of hybrid vigor through cross breeding between Clarias batrachus Lin, and Clarias gariepinus Bur. Aquaculture, 138(1-4): 125-130.

Samaradivakara SP, Hirimuthugoda NY, Gunawardana RHANM, Illeperuma RJ, Fernan- 
dopulle ND, De Silva AD, Alexander PABD. 2012. Morphological variation of four tilapia populations in selected reservoirs in Sri Lanka, Tropical Agricultural Research, 23(2): 105-116.

SAS. 1988. SAS/ STAT User's Guide, Release 6,03 Edition. ISBN 1-55544-088-6. SAS Institute Inc, Cary, NC, USA, 1028 p.

Setijaningsih L, Arifin OZ, Gustiano R, 2007. Karakterisasi tiga strain ikan gurami (Osphronemus gouramy Lac,) berdasarkan metode truss morfometrik, Jurnal Iktiologi Indonesia, 7(1): 23-30.

Su S, Xu P, Yuan X. 2013. Estimates of combining ability and heterosis for growth traits in a full diallel cross of three strains of three strains common carp, Cyprinus carpio L. African Journal of Biotechnology, 12(22): 3514-3521
Tave D. 1993, Genetics for Fish Hatchery Managers, $2^{\text {nd }}$ ed, AVI Publishing Company, Inc, Connecticut, $418 \mathrm{p}$.

Tave D. 1995. Selective breeding programmes for medium-sized fish farms, FAO Fisheries Technical Paper 352, Rome, FAO, 122 p

Tayamen, MM, Reyes RA, Danting MaD, Mendoza AM, Marquez EB, Salguet AC, Gonzales RC, Abella TA, Vera-Cruz EM. 2002. Tilapia broodstock development for saline water in the Philipines, Naga, 25(1): 32-36,

Wang X, Ross KE, Saillant E, Gatlin DM, Gold JR. 2006. Quantitative genetics and heritability of growth-related traits in hybrid striped bass (Morone chrysops $q \times$ Morone saxatilis §̂), Aquaculture, 261(2): 535-545.

Wohlfarth GW. 1993. Heterosis for growth rate in common carp, Aquaculture, 113(1-2): 3146. 